\title{
Structural Transformation in Central and Eastern European Countries' Agriculture: Convergence or Divergence?
}

\author{
Imre Fertö ${ }^{1,2}$ \\ ${ }^{1}$ Institute of Economics, Centre for Economic and Regional Studies, Hungarian Academy of Sciences, Hungary \\ ${ }^{2}$ Faculty of Economic Sciences, Kaposvar University, Hungary
}

Copyright $\bigcirc 2016$ by authors, all rights reserved. Authors agree that this article remains permanently open access under the terms of the Creative Commons Attribution License 4.0 International License

\begin{abstract}
The paper investigates the structural transformation of agriculture in Central and Eastern European countries using macro data in period between 1990 and 2011. The role of agriculture in total employment and GDP and the share of food expenditure have declined all analysed countries period in question. Our results indicate that despite of common trend the initial differences between countries have remained among countries. The findings of panel unit root tests do not confirm the convergence hypothesis in agricultural structural transformation of the region. The structural transformation does not follow common path in these countries. Our estimations also reinforces that the convergence analysis require careful application of various panel unit root tests.
\end{abstract}

Keywords Structural Transformation, Agriculture, Convergence, Central and Eastern Europe

\section{Introduction}

The role of agriculture in the economic development is an old subject for both theoretical and empirical research (e.g. Mundlak, [1], Timmer [2], Gollin [3]). The recent price soaring at the international food markets has shifted back the attention to the agriculture in economic development in both academic and political circles. The early view on the role of agriculture based on the dual economy model developed by Lewis [4] became popular in development economics in the 1960s and 1970s. In this model the agriculture is a backward unproductive sector from which production factors were to be drawn to help development of dynamic and productive industrial sector. Alternative view of agriculture (Johnston and Mellor [5], Schultz [6] and Gollin et al [7]) emphasises the significant contribution of agriculture to the economic growth. They argue that investments and policy reforms in agriculture might to lead to speed up the economic growth, although agriculture itself grows at slower rate than non-agricultural sector.

Timmer [8] analyses the paradoxical role of agriculture in structural transformation which may lead to the Lewis path of "a world without agriculture". He concludes that "the structural transformation has been the main pathway out of poverty for all societies, and it depends on rising productivity in both the agricultural and non-agricultural sectors"(p. 64). However, Dorin et al. [9] argue that the Lewis path is only one of four potential structural paths. Previous research focuses mainly on the developing countries, and the United States, but there is no paper on European transition countries. The paper tries to fill this gap. Previous research emphasise the role of initial condition in agricultural transition, the impact of economic and agricultural policy reforms, diversity of farm structures to explain the differences of agricultural performance of the Central and Eastern European(CEE) countries (e.g. Csáki and Nash [10], Csáki and Zuschlag [11], Lerman [12], Rozelle and Swinnen [13]). But they do not address directly the issue of the structural transformation. The aim of the paper is investigate the structural transformation of agriculture in CEE countries after 1990. Note, we focus only on a narrow dimension of this broad issue. Namely, we analyse whether these countries have followed the Lewis path in the last two decades. More specifically, is there a common agricultural development path in this region? The paper is structures as follows. First, we provide an overview on the structural indicators and the database. Then we briefly describe the empirical methodology of economic convergence. This is followed by the presentation of results and finally, we conclude.

\section{Data}

The standard indicators of the structural transformation on the supply side are usually the relative shares of sectoral contribution to the total employment or GDP (Herrendorf et al, [14]). Variables for empirical analysis are collected from 
the World Bank's World Development Indicator (WDI) database. More specifically, for dependent variables we use the agricultural value added in per cent of GDP (Agricultural GDP share), the employment in agriculture in per cent of total employment (Agricultural employment share). We analyse the period between 1990 and 2011. Our sample includes ten Central and Eastern European countries (Bulgaria, Czech Republic, Estonia, Hungary, Latvia, Lithuania, Poland, Romania, Slovakia and Slovenia). Note that data are not available for all countries during the analysed period, thus we have unbalanced panel dataset. On demand side we employ the share of food expenditure in the total expenditures (Food expenditure share) as a structural indicator. Data are based on the United Nation Statistic Division database. Note that food expenditure data also include the non-alcoholic beverages. Food expenditure data are not available for Romania; in addition majority of data is starting from 1995. Table 1 shows descriptive statistics for all indicators. Data (minimum and maximum values) reveal the considerable heterogeneity for each measure during analysed period.

Table 1. Descriptive statistics

\begin{tabular}{|c|c|c|c|c|c|}
\hline Variable & $\mathrm{N}$ & mean & $\begin{array}{c}\text { standard } \\
\text { deviation }\end{array}$ & minimum & maximum \\
\hline $\begin{array}{c}\text { Share of } \\
\text { agricultural } \\
\text { employments }\end{array}$ & 209 & 14.705 & 9.447 & 3 & 42.8 \\
\hline $\begin{array}{c}\text { Share of } \\
\text { Agricultural } \\
\text { GDP }\end{array}$ & 206 & 7.203 & 5.201 & 1.656 & 27.080 \\
\hline $\begin{array}{c}\text { Share of } \\
\text { Food } \\
\text { expenditures }\end{array}$ & 163 & 19.260 & 5.224 & 11.936 & 35.622 \\
\hline
\end{tabular}

Source: Own estimations

\section{Methodology}

Time series investigation of the convergence hypothesis in economic literature often relies on unit root tests. The rejection of the null hypothesis is commonly interpreted as evidence that the time series have converged to their equilibrium state, since any shock that causes deviations from equilibrium eventually drops out. The extension of these tests to the panel framework has significantly influenced the literature on how to measure the convergence of economic variables. Over the previous decade, a number of panel unit root tests have been developed (Baltagi [15]). Considering the well-known low-power properties of unit root tests, to check convergences or divergence in the $\mathrm{B}$ indices, three panel unit root tests with and without trend specifications, respectively, as deterministic components are used: the Im et al. [16] method (assuming individual unit root processes), ADF-Fisher Chi-square, and PP-Fisher Chi-square (Maddala and $\mathrm{Wu}$ [17]; Choi [18]). In addition, the lag length of explanatory variables has been chosen according to the Modified Akaike Information Criterion
(MAIC) proposed by Ng and Perron [19].

In order to test for convergence researchers usually apply either a cross-sectional or a time series framework (Sonderman [20]). However, the cross-sectional approach has been criticised recently for producing biased results (Quah [21, 22] Evans [23]; Sonderman [20]).

As an alternative time series approaches have been developed. According to Sonderman [20] the intuition behind this approach can be summarised as follows. Convergence can be assumed if idiosyncratic country-specific shocks only have temporary effects on productivity in a country relative to another country (or a country group average). In this case, the relative productivity levels would follow a stationary process. Without stationarity, relative productivity shocks would lead to permanent deviations. This definition of convergence, often referred to as stochastic convergence following Carlino and Mills [24] and Evans and Karras [25]. According to this definition, convergence can be tested in a unit root test framework.

Three main types of unit root tests can be distinguished: univariate root tests, first- and second generation panel unit root tests. Univariate unit root tests are only adequate to investigate convergence between two countries (Sonderman [20]) and they can lead to misleading results, especially in small- and moderate-sized sample. The extension of these tests to the panel framework has significantly influenced the literature. Over the previous decade, a number of panel unit root tests have been developed (see e.g. in Baltagi [15]). However, recent advancements in panel-data econometrics indicate that first generation panel unit root tests, which do not account for cross-sectional dependence (CD), tend to over reject the presence of unit roots (Baltagi [15]; Eberhardt and Teal [26]). This issue led to the development of second generation panel unit root tests, e.g. Bai and $\mathrm{Ng}$ [27] and Pesaran [28] panel unit root tests. These tests explicitly allow for $\mathrm{CD}$ in the data and therefore have better performance than first-generation panel unit root tests (Eberhardt-Teal [26]).

In our empirical analysis of convergence the assumption of cross-sectional independence appears to be unreasonable according to the literature, because various studies using cross-country data indicate that time series are contemporaneously correlated (Breitung and Pesaran [29]; Sonderman [20]). In order to check it empirically in the database used, before carrying out a panel unit root test, first we investigated the potential for $\mathrm{CD}$ in the obtained TFP scores, applying Pesaran [30] CD test. As it revealed evidence of $\mathrm{CD}$, we used second generation panel unit root test. However, some of the second generation panel unit root tests are require a panel dataset with large time dimension, e.g. the Bai and $\mathrm{Ng}$ [27] test. As in our dataset the time dimension is relatively small, we used the Pesaran [28] test, which perform accurately also with small samples (Moscone and Tosetti [31]). 


\section{Results}

In the first step we present our data using graphs. First striking feature of structural development: there is a considerable difference among CEE countries in the development of agricultural employment (Figure 1). Second important characteristics is that the decline of agricultural employment in last two decades. Simple graphical inspection confirms the prediction by Swinnen [33] on two different adjustment paths in agricultural labour market.

First group contains Bulgaria, Romania and partly Latvia and Lithuania with a relatively high level of agricultural employment at the beginning of economic transition. This group can be characterised by the increasing or stagnating level of agricultural employment in the nineties following by a drop of it in the second decade. Second group of countries is also started with a relatively high share of agricultural employment following by a drastic decrease in agricultural employment in the first five years (Estonia and Hungary). Czech Republic and Slovakia had a low level of agricultural employment in the early nineties which is declining continuously during analysed period. Poland started with a high level of agricultural employment following a continuous decrease, while Slovenian agricultural employment is varying around 10 percent.

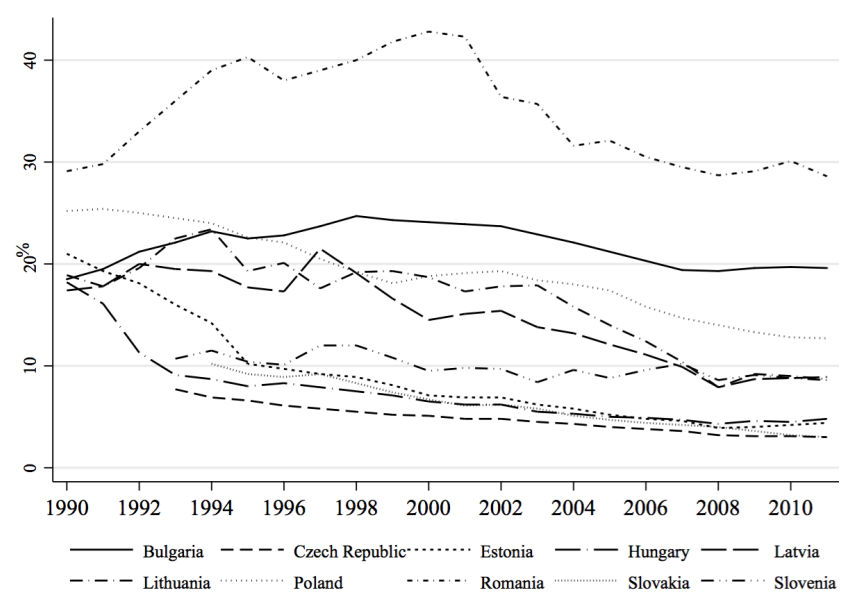

Source: World Bank [34] Word Development Indicator database

Figure 1. The share of agricultural employments between 1990 and 2011

In the early nineties the share of agricultural GDP displays a similar heterogeneity as emphasised by Lerman [12] or Swinnen and Rozelle [13]. The countries can be divided into three groups (Figure 2).

First, countries where agricultural GDP was above 30 percent, including Estonia, Lithuania and Romania. Second, countries with ratio of agricultural GDP between 10 and 20 per cent as Bulgaria and Hungary. Last group contains countries with less than 10 per cent agricultural GDP share at the beginning of transition. Despite of different starting position, the share of agricultural GDP has fallen below 10 per cent at the end of analysed period. In the first half of the nineties the rate of drop in agricultural GDP was strong in Estonia, Lithuania and Hungary.

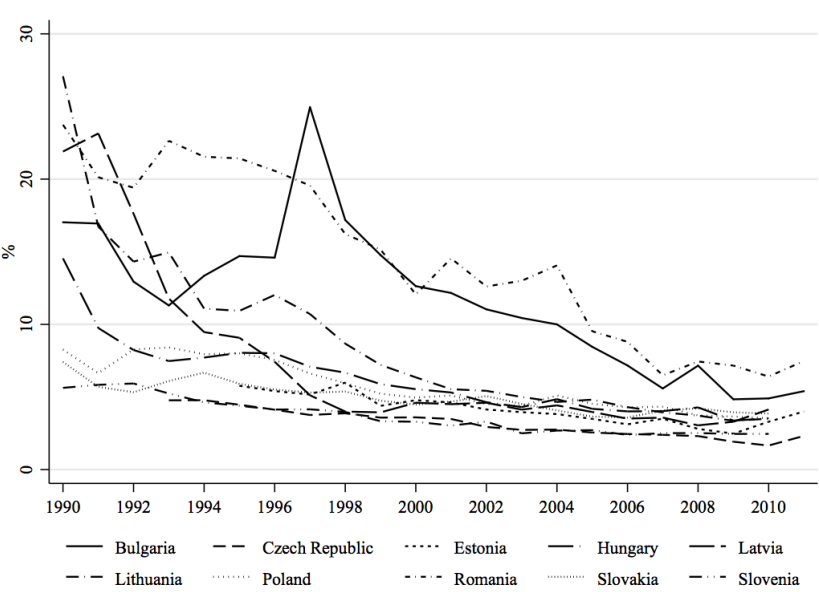

Source: World Bank [34] Word Development Indicator database

Figure 2. The share of agriculture in the GDP between 1990 and 2011

We can observe similar development on the consumption side according to the international trends (e.g. Herrendorf et al. [14]). The share of food expenditure has declined in all countries with considerable heterogeneity among them (Figure 3). In the middle of nineties the Baltic countries had the largest portion of food expenditures (around 30 per cent), while Slovenia had the smallest ones (16 per cent). Despite of general decreasing trends, the differences among countries had remained at the end of period in questions. Noteworthy is that the share of food expenditures exceeds significantly the ratio of agricultural GDP.

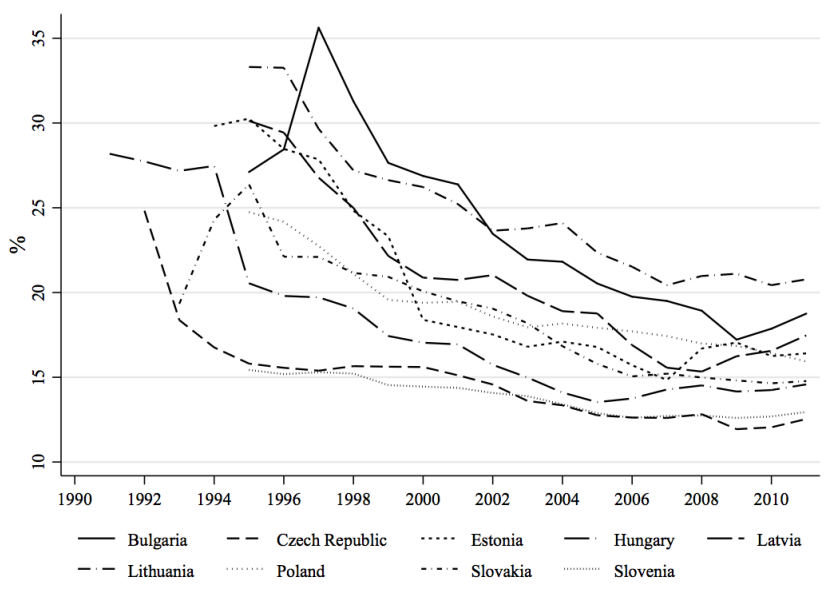

Source: United Nation Statistic Division database [35]

Figure 3. The share of food expenditures in total expenditures between 1992 and 2011

Table 2 shows the first generation panel unit root tests for all structural indicators without and with trends. Results for agricultural GDP and food expenditures are rather unambiguous. Seven of possible eight tests do reject the existence of panel unit root at one per cent of significance and one test reject at five per cent significance. In other words, our estimations indicate that the share of agricultural GDP and the ratio of food expenditures have converged during the analysed period. 
Table 2. Panel unit root tests ( $\mathrm{p}$ values)

\begin{tabular}{|c|c|c|c|}
\hline \multicolumn{4}{|c|}{ without trend } \\
\hline & $\begin{array}{c}\text { agricultural } \\
\text { employments }\end{array}$ & $\begin{array}{l}\text { agricultural } \\
\text { GDP }\end{array}$ & $\begin{array}{c}\text { food } \\
\text { expenditures }\end{array}$ \\
\hline $\begin{array}{c}\text { Levin, Lin and Chu } \\
\text { t stat }\end{array}$ & 0.0000 & 0.0000 & 0.0000 \\
\hline $\begin{array}{c}\text { Im, Pesaran and Shin } \\
\text { W-stat }\end{array}$ & 0.3362 & 0.0000 & 0.0004 \\
\hline $\begin{array}{c}\text { ADF - Fisher } \\
\text { Chi-square }\end{array}$ & 0.1029 & 0.0000 & 0.0001 \\
\hline PP - Fisher Chi-square & 0.0000 & 0.0000 & 0.0000 \\
\hline & $\begin{array}{c}\text { agricultural } \\
\text { employments }\end{array}$ & $\begin{array}{l}\text { agricultural } \\
\text { GDP }\end{array}$ & $\begin{array}{c}\text { food } \\
\text { expenditures }\end{array}$ \\
\hline \multicolumn{4}{|c|}{ with trend } \\
\hline $\begin{array}{c}\text { Levin, Lin and Chu } \\
\text { t stat }\end{array}$ & 0.1837 & 0.0000 & 0.0000 \\
\hline $\begin{array}{c}\text { Im, Pesaran and Shin } \\
\text { W-stat }\end{array}$ & 0.4533 & 0.0001 & 0.0162 \\
\hline $\begin{array}{c}\text { ADF - Fisher } \\
\text { Chi-square }\end{array}$ & 0.2867 & 0.0000 & 0.0005 \\
\hline PP - Fisher Chi-square & 0.0008 & 0.0000 & 0.0004 \\
\hline
\end{tabular}

Source: Own estimations

We cannot derive similar strong conclusions for the agricultural employment. Five of possible eight tests can not reject the null hypothesis of panel unit root. More importantly three tests of four with trends show similar results. This is particularly important because graphical inspection of data imply trend effects.

The literature on panel unit root tests emphasises the issue of cross-sectional dependence especially for first generation panel unit root tests. Thus we check the existence of cross-sectional dependence using test developed by Pesaran [31]. Our estimations clearly indicate that we can reject the null-hypotheses of cross-sectional interdependence for all indicators (Table 3). It implies that we need to employ second generation panel unit root tests to correct the problem of cross-sectional dependence.

Table 3. Pesaran tests for cross-sectional dependence

\begin{tabular}{|c|c|c|c|c|}
\hline Variable & CD-test & $\mathrm{p}$ value & correlation & $\mid$ correlation $\mid$ \\
\hline $\begin{array}{c}\text { Share of } \\
\text { agricultural } \\
\text { employments }\end{array}$ & 20.81 & 0.000 & 0.700 & 0.712 \\
\hline $\begin{array}{c}\text { Share of } \\
\text { Agricultural GDP }\end{array}$ & 24.57 & 0.000 & 0.830 & 0.830 \\
\hline $\begin{array}{c}\text { Share of Food } \\
\text { expenditures }\end{array}$ & 22.42 & 0.000 & 0.900 & 0.900 \\
\hline
\end{tabular}

Source: Own estimations

Thus in the final step we employ panel unit root tests developed by Pesaran [28]. Because using this test we cannot apply any information criteria to identify the appropriate lag length, thus we present our results from 0 to 4 years lag length with and without trend.

Surprisingly, Pesaran [28] tests strongly modify our previous results. Seven of ten tests for agricultural employment do reject the panel unit root null hypotheses (Table 4). In other words, contrary to results based on first generation panel unit root tests, new estimations support rather the convergence hypothesis. Results for food expenditures also indicate opposite outcome comparing to earlier estimations, seven of ten tests for agricultural employment do not reject the panel unit root null hypotheses. The half of tests does not reject the null hypothesis of panel unit root for the agricultural GDP share. Furthermore, our estimations favour the acceptance of unit root null hypothesis for specification with time trend. It implies rather diverge development in the share of agricultural GDP.

Table 4. Pesaran panel unit root tests ( $\mathrm{p}$ values)

\begin{tabular}{|c|c|c|c|c|c|c|}
\hline & \multicolumn{2}{|c|}{ agricultural employments } & \multicolumn{2}{c|}{ agricultural GDP } & \multicolumn{2}{c|}{ Food expenditures } \\
\hline lags & without trend & with trend & without trend & with trend & without trend & with trend \\
\hline 0 & 0.002 & $\mathbf{0 . 2 7 0}$ & 0.000 & 0.000 & $\mathbf{0 . 0 8 0}$ & $\mathbf{0 . 5 4 8}$ \\
\hline 1 & 0.000 & 0.003 & 0.000 & 0.000 & 0.000 & 0.004 \\
\hline 2 & 0.000 & 0.013 & 0.001 & $\mathbf{0 . 3 4 6}$ & 0.006 & $\mathbf{0 . 9 5 9}$ \\
\hline 3 & 0.043 & $\mathbf{0 . 0 9 5}$ & $\mathbf{0 . 5 6 5}$ & $\mathbf{0 . 6 4 0}$ & $\mathbf{0 . 0 8 5}$ & $\mathbf{0 . 9 9 0}$ \\
\hline 4 & 0.000 & $\mathbf{1 . 0 0 0}$ & $\mathbf{1 . 0 0 0}$ & $\mathbf{0 . 9 7 7}$ & $\mathbf{1 . 0 0 0}$ & $\mathbf{1 . 0 0 0}$ \\
\hline
\end{tabular}

Source: Own estimations 


\section{Conclusions}

The aim of the paper is to investigate whether does agriculture in CEE countries converge or diverge to each other between 1990 and 2011. We employ both first and second generation panel unit root tests to analyse the structural convergence. Due to existence of cross-sectional dependency our results should rely more on second generation tests. Our estimations suggest that agriculture in CEE countries has not followed a common development path. We emphasise that further research is needed to understand the structural convergence in this region. Natural extension of our research employs other second generation panel unit root tests. However, new estimations can yield also inconvenient results, namely we cannot conclude unambiguously on structural convergence. Finally our results confirm Hurlin [33] findings that is testing panel unit root in macro data require a very careful investigation without a hope of conclusive results.

\section{Acknowledgements}

The author gratefully thanks the useful suggestions and comments by Štefan Bojnec, Csaba Csáki, Takashi Kurosaki, Ichiro Iwasaki and the Economic. Development workshop participants at the Hitotsubashi University.

\section{REFERENCES}

[1] Mundlak, Y. Agriculture and Economic Growth: Theory and Measurement. Cambridge and London: Harvard University Press, 2000

[2] Timmer, C P. (Agriculture and economic development. In. Gardner, B.L. and Rausser, G.C. (eds.) Handbook of Agricultural Economics, 2A, Elsevier Science, Amsterdam, 2002, 1487-1546.

[3] Gollin, D. Agricultural productivity and economic growth. In: Pingali, P. and Evenson, R. (eds.) Handbook of Agricultural Economics, Vol. 4, Elsevier Science, Amsterdam, 2010. $3825-3866$.

[4] Lewis, W.A. Economic development with unlimited supplies of labour. The Manchester School Vol.22. No.1. 139-91. 1954

[5] Johnston, B.F., and Mellor, J.W.. The role of agriculture in economic development." The American Economic Review Vol.51. No.4. 566-593. 1961

[6] Schultz, T. W. Transforming traditional agriculture. Transforming traditional agriculture. New Haven: Yale University Press. 1964

[7] Gollin, D., Lagakos, D., \& Waugh, M. E. Agricultural productivity differences across countries. The American Economic Review, Vol.104. No. 5. 165-170. (2014).

[8] Timmer, C.P. A world without agriculture: The structural transformation in historical perspective. AEI Press. 2009
[9] Dorin, B., J. C., Hourcade, and M. Benoit-Cattin AWorld without Farmers? The Lewis Path Revisited, Working Paper, Cired (No. hal-00866413): HAL. 2013

[10] Csáki, Cs. and Nash, J. The Agrarian Economies of Central and Eastern Europe and the Commonwealth of Independent States. World Bank Discus. Pap. 387, Washington DC. 1997

[11] Csáki, Cs. and Zuschlag, A. The Agrarian Economies of Central-Eastern Europe and the CIS. ECSSD Environmentally and Socially Sustainable Development, Work. Pap. 37, Washington DC. 2003

[12] Lerman, Z. Agriculture in Transition Economies: from Common Heritage to Divergence. Agricultural Economics Vol.26. No.2. 95-114. 2001

[13] Rozelle, S., and Swinnen, J. F. Success and failure of reform: Insights from the transition of agriculture. Journal of Economic Literature, Vol.42. No.2. 404-456. 2004

[14] Herrendorf, B., Rogerson, R. and Valentinyi, Á. Growth and Structural Transformation. In: Aghion, P. and Durlauf, S.N. (eds.): Handbook of Economic Growth Vol. 2, Elsevier, pp. 855-941, 2013

[15] Baltagi, B.H. Econometric Analysis of Panel Data. 4th ed. Wiley. New York. 2008

[16] Im KS,, Pesaran, M.H. and Shin, Y. Testing for unit roots in heterogeneous panels. Journal of Econometrics Vol. 115. No.1. 53-74. 2003

[17] Maddala, G.S. and Wu, S. A Comparative Study of Unit Root Tests with Panel Data and a New Simple Test. Oxford Bulletin of Economics and Statistics, Vol.61. S1. 631-652. 1999

[18] Choi, I. Unit root tests for panel data. Journal of international money and Finance, Vol.20. No.2, 249-272. 2001.

[19] Ng, S. and Perron, P. Lag length selection and the construction of unit root tests with good size and power. Econometrica Vol.69. No.6. 1519-1554. 2001

[20] Sondermann, D. Productivity in the euro area: any evidence of convergence?. Empirical Economics Vol.47. No.3. 999-1027. 2014:

[21] Quah D. Galton's fallacy and tests of the convergence hypothesis. Scandinavian Journal of Economics Vol. 95. 427-443. 1993

[22] Quah D. Empirics for growth and distribution: stratification, polarization, and convergence clubs. Journal of Economic Growth Vol.2. No.1.27-59. 1997

[23] Evans P. Using panel data to evaluate growth theories. International Economic Review Vol.39. 295-306 1998

[24] Carlino GA, Mills L Are US regional incomes converging? Journal of Monetary Economics Vol.32. No.2. 335-346. 1993

[25] Evans P, Karras G. Convergence revisited. Journal of Monetary Economics Vol.37: No.2. 249-265. 1996

[26] Eberhardt, M. and Teal, F. Econometrics for grumblers: A new look at the literature on cross-country growth empirics. Journal of Economic Surveys Vol.25. No.1. 109-155. 2011

[27] Bai, J. and Ng, S. A PANIC attack on unit roots and cointegration, Econometrica, 72, 1127-78. (2004) 
[28] Pesaran, M.H. A simple panel unit root test in the presence of cross-section dependence. Journal of Applied Econometrics, Vol. 22(2): 265-312. (2007)

[29] Breitung J, Pesaran MH (2007) Unit roots and cointegration in panels. In: Matyas L, Sevestre P (eds) The econometrics of panel data: fundamentals and recent developments in theory and practice. Kluwer Academic Publishers, Boston

[30] Pesaran, M.H. General Diagnostic Tests for Cross Section Dependence in Panels. Working Papers in Economics. No. 0435. University of Cambridge. Cambridge. (2004)

[31] Moscone, F. and Tosetti, E. A review and comparison of tests of cross-section independence in panels. Journal of Economic Surveys 23(3): 528-561. (2009)

[32] Hurlin, C. What would Nelson and Plosser find had they used panel unit root tests? Applied Economics 42:1515-1531 (2010)

[33] Swinnen, J.F.M. Reforms, Globalization, and Endogenous Agricultural Structures. Agricultural Economics, 40(1): 719-732. (2009)

[34] World Bank. World Development Indicators. Washington, D.C. Available at: http://data.worldbank.org 2013.

[35] United Nation Statistic Division database, 2014. 